\title{
PUBLICATIONS
}

The following list of publications was compiled by Mr. J. W. Michaud, Director of Publicity and Information, Department of Lands and Forests, Quebec:-

R. Pomerleau, D.Sc.

"Observation sur quelques maladies non-parasitaires des arbres du

Québec" Can. Journal of Research. Sec. C. No. 2. 171-189-1944.

"Les maladies de l'érable à sucre et leur prevention"

La Forêt Québecoise-Avril. 1944.

R. Gosselin, F.E., Ph.D.

"Studies on Polystictus Circinatus and its relation to butt-rot of spruce".

Bulletin No. 10 (New series) 1944. Forest Service Quebec.

Association Forestière Québecoise

Compte-rendu du ler Congrès Provincial tenu à Québec, les 3-4 octobre 1944. 437 pages. Price: $\$ 1.50$.

La forêt

Ecole des Hautes Etudes Commerciale - Montréal. 414 pages - Price $\$ 1.50$.

Vocabulaire en usage dans les industries du bois (French and English) 60 pages. Forest Service-Quebec.

R. Lelisle, F.E.

Le boisé de la Farme-163 pages. Price \$0.25. U.C.C.-515 Viger Avenue, Montréal.

Geo. H. Bernier, F.E.

Cours sur le brûlage des abatis à l'usage des inspecteurs et des gardes-feu. 35 pages. Service de la protection des forêts. Québec.

Geo. H. Bernier, F.E.

La protection des forêts contre lincendie.-130 pages.

\section{OPENINGS FOR FORESTERS}

Mr. G. E. LeMothe, Assistant to the Vice-President in charge of Woodlands, Price Brothers and Company Ltd., Quebec, advises that there are openings for Forest Engineers with his company. Any enquiries should be marked for the attention of $\mathrm{Mr}$. LeMothe. 